\title{
Fluktuasi Fitoplankton pada Kawasan Konservasi Rajungan Perairan Betahwalang Demak
}

\author{
Elsa Lusia Agus*, Rudhi Pribadi dan Subagiyo
}

\begin{abstract}
Departemen IImu Kelautan, Fakultas Perikanan dan IImu Kelautan, Universitas Diponegoro JI. Prof. Soedarto, SH. Kampus UNDIP Tembalang, Semarang 50275

Email : Iusiaelza@gmail.com
\end{abstract}

\section{Abstract \\ Phytoplankton in the Blue Swimming Crabs Conservation Area Betahwalang Demak Waters}

Phytoplankton is an organism that had an effect on life waters and can be used as the parameters in monitoring water quality. Distribution of phytoplankton in the waters can be for biomonitoring which can be used to make protection zone. This study will examine the distribution and composition of phytoplankton in The crab conservation area in Betahwalang Waters, Demak. This research divided into three stations in estuaries and the sea s. Each sampling was done once a month. Samples were taken using a plankton net. The results found three classes of phytoplankton, namely Bacillariophyceae class, Cyanophyceae class and Dinophyceae class. The number of genera found in the river area (37 genera), at the estuary station as much (38 genera) and the sea station as much (31 genera). Fluctuation in phytoplankton abundance at each station is quite varied. The abundance of phytoplankton in January was 1.030 .400 cells/L, in February it was 936.800 cells/L, and in March it was 643.600 cells/L. The highest abundance occurs in the estuary area, then the river and the lowest in the sea. The value of species diversity index ( $H$ ') is in the range of 2.57-3.03. Uniformity index values range from 0.86 to 0.94 . The dominance index from 0.06 to 0.14 . Factors affecting the abundance and dominance of phytoplankton are water conditions and the rainy season.

Keywords :Distribution; Abundance; Phytoplankton; Demak

\begin{abstract}
Abstrak
Fitoplankton merupakan organisme yang mempunyai pengaruh besar terhadap kehidupan di suatu perairan baik langsung maupun tidak langsung dan dijadikan sebagai salah satu parameter dalam pemantavan kualitas perairan. Fitoplankton di perairan dapat dijadikan suatu ukuran bahwa Kawasan tersebut dapat dijadikan sebagai zona perlindungan biota.Penelitian ini mengkaji fluktuasi fitolankton pada Kawasan konservasi rajungan di Perairan Betahwalang, Demak. Penelitian ini dilakukan pada 3 stasiun yang terletak disungai, muara sungai, dan laut. Pengambilan sampel dilakukan setiap bulan selama tiga bulan menggunakan planktonnet. Hasil penelitian ditemukan 3 kelas yaitu kelas Bacillariophyceae, Cyanophyceae dan Dinophyceae.Jumlah genus yang ditemukan pada area sungai, muara sungai dan laut berturutturut 37 genus, 38 genus dan 31 genus. Fluktuasi kelimpahan fitoplankton di setiap stasiun cukup bervariasi.Kelimpahan fitoplankton pada bulan Januari sebesar $1.030 .400 \mathrm{sel} / \mathrm{L}$, pada bulan Februari sebesar $936.800 \mathrm{sel} / \mathrm{L}$, dan pada bulan Maret sebesar $643.600 \mathrm{sel} / \mathrm{L}$. Kelimpahan tertinggi terjadi pada daerah muara, kemudian sungai dan terendah di laut. Sedangkan nilai indeks keanekaragaman jenis ( $H^{\prime}$ ) berada pada kisaran 2,57-3,03. Nilai indeks keseragaman berkisar 0,860,94 . Sedangkan indeks dominasi berkisar 0,06-0,14. Faktor yang mempengaruhi kelimpahan dan dominasi fitoplankton adalah kondisi perairan dan musim hujan.
\end{abstract}

Keywords :Distribusi; Kelimpahan; Fitoplankton; Demak 


\section{PENDAHULUAN}

Demak khususnya Betahwalang merupakan daerah pesisir yang wilayahnya banyak dialiri Sungai maupun Kanal. Sebagian besar pesisir daratanya dimanfaatkan untuk pertanian, pertambakan dan pemukiman. Sungai maupun Kanal yang melawati daerah tersebut tentunya akan membawa berbagai buangan terutama limbah organik yang tentunya akan membawa pengaruh pada kesuburan perairan Betahwalang. Hal tersebut terlihat dengan vegetasi mangrove yang tumbuh sepanjang pantai dan warna air yang terlihat hijau yang menunjukan tingginya fitoplankton yang ada. Tingginya fitoplankton di suatu perairan tentunya didukung oleh faktor lingkungan seperti nutrient, suhu, salinitas, $\mathrm{pH}$, CO2 dan intesitas cahaya. Fitoplankton merupakan organisme yang mempunyai pengaruh besar terhadap kehidupan di suatu perairan baik langsung maupun tidak langsung dan dijadikan sebagai salah satu parameter dalam pemantauan kualitas perairan. Bebarapa penelitian menunjukan bahwa kelimpahan jenis dan keragaman jenis fitoplankton dapat berubah dengan cepat ketika kondisi lingkungan laut berubah (Youyin, 2018), sehingga komposisi jenis fitoplankton dianggap sebagai indikator biologis ekosistem laut (Ghinaglia et al., 2004). Namun pada saat yang sama ledakan populasi fitoplankton dapat mematikan ekosistem, seperti kekurangan oksigen pada ekosistem terumbu. Sebagai contoh, pengamatan komunitas terumbu karang di utara Florida menunjukkan penurunan yang signifikan, studi terkait menunjukkan booming fitoplankton terjadi di Teluk Persia selama 10 bulan, yang menyebabkan kematian massal karang di wilayah tersebut (Ye et al., 2019). Fitoplankton memegang peranan yang sangat penting dalam suatu perairan. Fungsi ekologinya sebagai produsen primer dan awal mata rantai dalam jaring makanan menyebabkan fitoplankton sering dijadikan skala ukuran kesuburan suatu perairan. Fitoplankton selain berfungsi dalam keseimbangan ekosistem perairan, juga merupakan produsen atau sumber daya pakan bagi ikan (Marsambuana, 2008).

Fitoplankton ada di mana-mana di berbagai lingkungan perairan dan sebagai produsen utama ekosistem perairan, fitoplankton memainkan peran yang tak tergantikan dalam aliran energi dan siklus nutrisi (Behrenfeld dan Boss, 2014). Sebagai contoh dalam budidaya udang, sisa pakan dan metabolit dari udang didekomposisi menjadi nutrisi oleh bakteri (Kumar et al., 2016), dan nutrisi ini kemudian digunakan oleh fitoplankton, meningkatkan kelimpahannya (Yang et al., 2019). Sebagai imbalannya untuk lingkungan fitoplankton dapat menghilangkan amonia dan nitrit yang menekan sistem kekebalan udang (Liao et al., 2012) dari sistem budidaya, yang dapat berfungsi sebagai pengatur yang sangat baik dan indikator kualitas air (Case et al., 2008). Selain itu, bahan organik terlarut (DOM) yang dikeluarkan dari fitoplankton yang sehat (Landa et al., 2016; Logue et al., 2016). Sebagai konsekuensinya, fitoplankton memiliki kapasitas untuk mengelola lingkungan dalam budidaya udang

Fluktuasi fitoplankton di perairan dapat dijadikan suatu ukuran bahwa kawasan tersebut dapat dijadikan sebagai zona perlindungan biota. Berbagai uraian diatas menunjukkan bahwa perlunya kajian mengenai fluktuasi fitoplankton di kawasan konservasi atau perlindungan, terlebih pada kawasan konservasi rajungan di Perairan Betahwalang yang belum mempunyai kajian akan kelimpahan fitoplankton. Penelitian ini akan mengkaji fluktuasi jenis fitolankton pada kawasan konservasi rajungan di Perairan Betahwalang, Demak.

\section{MATERI DAN METODE}

Materi yang digunakan dalam penelitian ini adalah fitoplankton yang diambil dari Kawasan Konservasi Rajungan di Perairan Betahwalang, Demak.

Pengumpulan data dengan sample survey method yaitu metode pengumpulan data dengan cara mencatat sebagian kecil populasi hasilnya diharapkan dapat menggambarkan dari sifat populasi yang diselidiki.Penelitian ini dilakukan pada 3 stasiun (stasiun yang berlokasi sungai, muara sungai, dan laut) dengan 5 sub stasiun. Pengambilan sampel dilakukan setiap bulan selama tiga bulan menggunakan planktonnet.

Sampel air yang berisi plankton yang 
diperoleh dimasukkan kedalam botol sampel sebanyak $200 \mathrm{ml}$ dan diawetkan dengan menambahkan larutan formalin $4 \%$. Selanjutnya sampel yang telah diperoleh dibawa ke laboratorium untuk diidentifikasikan menggunukan mikroskop dan buku identifikasi (Yamaji, 1996).Analisis data kelimpahan fitoplankton dihitung berdasarkan persamaan menurut APHA (1989).Perhitungan indeks keanekaragaman menggunakan rumus Romimohtarto dan Juwana (2001). Kisaran Indeks Keanekaragamanadalah $0-1=$ sangat rendah ; 1-2=rendah; $2-3=$ sedang; $3-4=$ tinggi; $4-5=$ sangat tinggi; $>5=$ maksimum. Indeks keseragaman dapat dihitung dengan rumus. Menurut Odum (1998) besarnya indeks keseragaman jenis berkisar antara $0-1$, dimana: $e>0,6=$ Keseragaman jenis tinggi; $0,4<e<0,6$ : Keseragaman jenis sedang; $e<0,4$ : Keseragaman jenis rendah.

Suatu perairan yang mempunyai keanekaragaman jenis rendah cenderung memiliki keseragaman yang rendah pula.Nilai indeks keseragaman (e) dan indeks dominasi (D) berkisar antara 0-1. Jika nilai indeks keseragaman mendekati 0 maka nilai indeks dominasi akan mendekati 1. Hal ini berarti jika keseragaman suatu populasi semakin kecil, maka ada kecenderungan suatu jenis mendominasi suatu populasi tersebut (Odum, 1998).Menurut Odum (1998) indeks dominansi adalah derajat pada dominansi dari satu, atau beberapa banyak spesies.Berdasarkan Odum (1998), dominansi hasil perhitungan adalah sebagai berikut :D mendekati 0 tidak ada jenis yang mendominansi dan $D$ yang mendekati 1 terdapat jenis yang mendominansi. Menurut Odum (1998) kriteria indek dominansi dibagi menjadi dua, yaitu: $0<D<0,5$ : tidak ada spesies yang mendominansi $0,5<\mathrm{D}<1$ : terdapat spesies yang mendominansi

\section{HASIL DAN PEMBAHASAN}

Berdasarkan hasil pengamatan fitoplankton yang dilakukan pada Perairan Betahwalang, Demak ditemukan 3 kelas pada tiga stasiun yaitu sungai, muara dan laut, ditemukan (38 genus) terdiri dari 3 kelas, yaitu kelas Bacillariophyceae, kelas Cyanophyceae dan kelas Dinophyceae (Gambar 1). Jumlah genus yang ditemukan pada area sungai yaitu (37 genus), pada stasiun muara sebanyak (38 genus) dan pada stasiun laut sebanyak (31 genus).

Hasil penelitian menunjukan Kelas Bacilariophyceae tertinggi ditemukan pada daerah muara di bulan Januari, Februari dan Maret sebanyak (28 genus). Genus terbanyak yang ditemukan selama penelitian adalah skeletonema yaitu sebanyak $905 \mathrm{sel} / \mathrm{L}$. Hasil penelitian menunjukan bahwa genus yang selalu ditemukan pada setiap bulannya adalah Melosira,Skeletonema, Stephanopyxis, Leptocylindrus, Coscinodiscus, Rhizosolenia, Bacteriastrum, Chaetoceros, Biddulphia, Thalasiothrix, Thalasionema, Climacospenia, Eucamphia, Gyrosigma, Pleurosigma, Brachisyra, Navicula, Isthmian, Nitzschia, Oscillatoria, Ceratium, Gonyaulax, Noctiluca dan Peridinium. Kelas acilariophyceae mendominasi di setiap stasiun sungai, muara, dan laut. Hal tersebut sesuai dengan (Ariana et al., 2014) yang mengatakan bahwa kelas ini mendominasi di perairan karena bacillariophyceae (Diatom) diduga karena fitoplankton yang termasuk dalam kelas ini mempunyai adaptasi yang tinggi dan ketahanan hidup pada berbagai kondisi perairan termasuk kondisi ekstrim. Penelitian yang dilakukan oleh Putri et al., (2019) bahwa kelas Bacillariophyceae mendominasi di Perairan Morosari Demak.

Menurut Odum (1998), banyaknya kelas Bacillariophyceae (Diatom) di perairan disebabkan oleh kemampuannya beradaptasi dengan lingkungan, bersifat kosmopolit, tahan terhadap kondisi ekstrim serta mempunyai daya reproduksi yang tinggi. Praseno dan Sugestiningsih (2000) menyatakan bahwa pada saat terjadi peningkatan konsentrasi zat hara, diatom mampu melakukan reproduksi tiga kali dalam 24 jam, sedangkan dinoflagellata hanya mampu melakukannya satu kali dalam 24 jam pada kondisi zat hara yang sama.

Menurut Madinawati (2012), tingginya kelimpahan Bacillariophyceae disebabkan karena organisme ini dominan ditemukan di perairan muara, karena daerah muara banyak aliran sungai yang membawa nutrien seperti nitrat dan fosfat. Kelimpahan genus tertinggi fitoplankton pada bulan Januari diasumsikan karena pada bulan tersebut terjadi musim hujan. Musim hujan mengakibatkan meningkatnya nutrien seperti 
fosfat dan nitrat di perairan (Meirinawati dan Muchtar, 2017). Selanjutnya, pada bulan Januari terjadi musim gelombang mengakibatkan pengadukan substrat di dasar perairansehingga perairan tersebut menjadi subur, dan menyebabkan kelimpahan beberapa genus fitoplankton pada bulan Februari menjadi tinggi. Kelimpahan terendah terjadi pada bulan Maret, hal ini dikarenakan kondisi perairan pada bulan Maret sudah tenang, dan tidak terjadi pengadukan seperti halnya pada bulan Februari. Sehingga kelimpahan genus fitoplankton akan menurun setelah musim penghujan. Kelimpahan tertinggi fitoplankton ditemukan pada bulan Januari di stasiun muara dengan kelimpahan sebanyak $465.600 \mathrm{sel} / \mathrm{L}$. Sedangkan kelimpahan terendah ditemukan pada bulan Maret di stasiun Laut dengan kelimpahan sebanyak $152.000 \mathrm{sel} / \mathrm{L}$.

Fluktuasi populasi fitoplankton di setiap stasiun cukup bervariasi.Berdasarkan hasil pengamatan fitoplankton pada setiap bulannya didapatkan hasil bahwa Kelimpahan fitoplankton tertinggi terjadi di bulan januari untuk setiap stasiunnya hal ini disebabkan karena pada bulan tersebut intensitas hujan yang cukup rendah, sehingga intesistas cahaya matahari yang masuk diperairan mampu untuk melakukan fotosintesis. Fitoplankton mengandung klorofil yang mempunyai kemampuan berfotosintesis yakni menyadap energi matahari untuk mengubah bahan inorganik menjadi bahan organik (Nontji, 2006).

Fitoplankton dalam melakukan

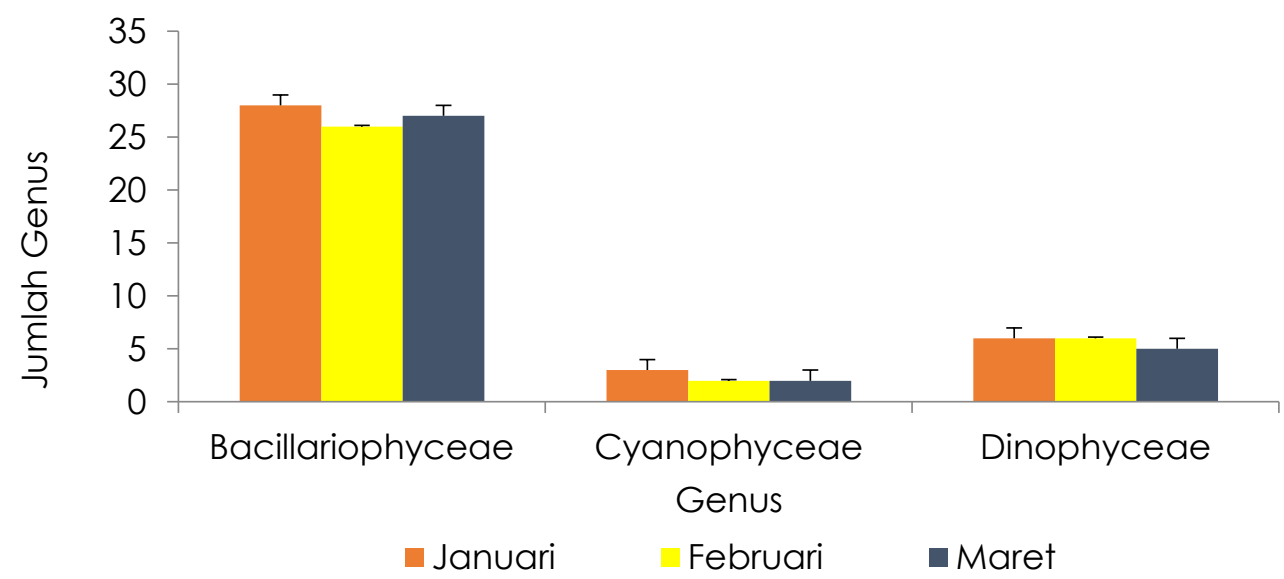

Gambar 1. Fluktuasi jumlah genus fitoplankton yang ditemukan pada Kawasan konservasi rajungan di Perairan Betahwalang, Demak. fotosintesis membutuhkan cahaya matahari. Penyinaran cahaya matahari berkurang secara cepat dengan makin tingginya kedalaman. Ini sebabnya fitoplankton sebagai produsen primer hanya didapat pada daerah atau kedalaman dimana sinar matahari dapat menembus pada perairan (Hutabarat dan Evans, 1986).

Kelimpahan fitoplankton tertinggi ditemukan di daerah muara hal ini sesuai dengan pernyataan sihombing et al. (2013), bahwa keberadaan fitoplankton banyak ditemukan di permukaan perairan yang dekat dengan darat (muara) karena daratan banyak menyediakan nutrien seperti nitrat dan fosfat di perairan.

Hasil analisis indeks keanekaragaman, indeks keseragaman dan indeks dominansi fitoplankton di Daerah Konservasi Rajungan, Betahwalang disajikan pada Tabel 1.Hasil pengamatan pada setiap stasiun menunjukkan hasil yang tidak berfluktuatif. Nilai indeks keanekaragaman jenis $\left(H^{\prime}\right)$ berada pada kisaran 2,57-3,03. Nilai indeks keseragaman berkisar 0,86-0,94. Sedangkan indeks dominasi berkisar 0,06-0,14. Nilai indeks keanekaragaman di sumua stasiun termasuk kedalam kategori sedang, dimana hanya terdapat satu stasiun yang berkategori tinggi yaitu stasiun Muara di bulan Januari dengan indeks keanekaragam $(3,03)$. Sedangkan nilai indeks keseragaman pada semua stasiun mempunyai nilai yang termasuk kategori tinggi. Dominasi spesies tidak terjadi pada semua stasiun, hal tersbut mengindikasikan bahwa di Kawasan Konservasi Rajungan di Perairan Betahwalang tidak terjadi dominasi spesies. Hal tersebut sesuai dengan 


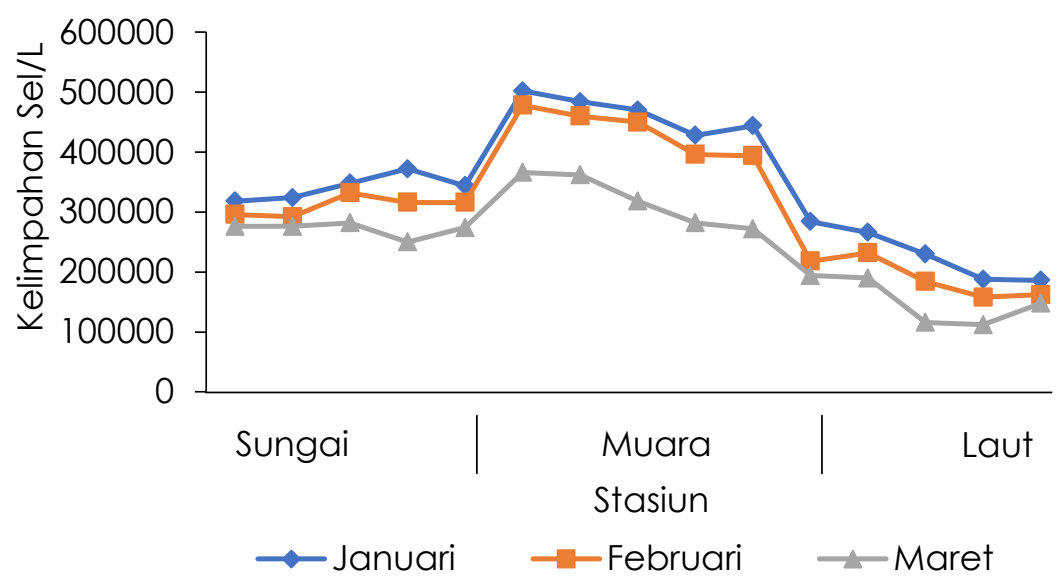

Gambar 2. Fluktuasi Kelimpahan Fitoplankton Di Kawasan Konservasi Rajungan Desa Betahwalang, Demak

Tabel 1. Keanekaragaman, Keseragaman, dan Dominasi Fitoplankton yang ditemukan pada Kawasan konservasi rajungan di Perairan Betahwalang, Demak.

\begin{tabular}{|c|c|c|c|c|c|c|}
\hline \multirow{2}{*}{ Stasiun } & \multicolumn{6}{|c|}{ Bulan Pengamatan Januari } \\
\hline & $\mathrm{H}^{\prime}$ & Kategori & $E$ & Kategori & D & Kategori \\
\hline Sungai & 2,95 & Sedang & 0,89 & Tinggi & 0,11 & TAD \\
\hline Muara & 3,03 & Tinggi & 0,86 & Tinggi & 0,14 & TAD \\
\hline Laut & 2,68 & Sedang & 0,93 & Tinggi & 0,07 & TAD \\
\hline \multirow{2}{*}{ Stasiun } & \multicolumn{6}{|c|}{ Bulan PengamatanFebruari } \\
\hline & $\mathrm{H}^{\prime}$ & Kategori & $E$ & Kategori & D & Kategori \\
\hline Sungai & 2,84 & Sedang & 0,90 & Tinggi & 0,10 & TAD \\
\hline Muara & 2,95 & Sedang & 0,87 & Tinggi & 0,13 & TAD \\
\hline Laut & 2,57 & Sedang & 0,94 & Tinggi & 0,06 & TAD \\
\hline \multirow{2}{*}{ Stasiun } & \multicolumn{6}{|c|}{ Bulan PengamatanMaret } \\
\hline & $\mathrm{H}^{\prime}$ & Kategori & $E$ & Kategori & D & Kategori \\
\hline Sungai & 2,84 & Sedang & 0,90 & Tinggi & 0,10 & TAD \\
\hline Muara & 2,97 & Sedang & 0,88 & Tinggi & 0,12 & TAD \\
\hline Laut & 2,58 & Sedang & 0,93 & Tinggi & 0,07 & TAD \\
\hline
\end{tabular}

(Madinawati, 2010) menyatakan bahwa jika terjadi dominasi fitoplankton dalam suatu kawasan atau perairan, maka perairan tersebut dapat dikategorikan perairan yang tidak seimbang karena telah terjadi pencemaran limbah ke perairan. Hasil uji anova $\mathrm{p}=0,003<0,01$ menunjukan adanya perbedaan yang sangat nyata antara kelimpahan antar waktu sampling.

\section{KESIMPULAN}

Berdasarkan pengamatan fitoplankton yang dilakukan pada Perairan Betahwalang, Demak ditemukan 3 kelas Hasil penelitian menunjukan bahwa genus yang selalu ditemukan pada setiap bulannya adalah Melosira, Skeletonema, Stephanopyxis, Leptocylindrus, Coscinodiscus, Rhizosolenia,
Bacteriastrum, Chaetoceros, Biddulphia, Thalasiothrix, Thalasionema, Climacospenia, Eucamphia, Gyrosigma, Pleurosigma, Brachisyra, Navicula, Isthmian, Nitzschia, Oscillatoria, Ceratium, Gonyaulax, Noctiluca dan Peridinium. Berdasarkan Uji One Way Anova tentang perbedaan kelimpahan fitoplankton pada semua stasiun adalah berbeda nyata $(p<0.01)$.

\section{DAFTAR PUSTAKA}

American Public Health Association (APHA).1989. Standard methods for the examination of water and wastewater, 17.

Ariana, D., Samiaji, J., \& Nasution, S. 2014. Komposisi jenis dan kelimpahan fitoplankton perairan laut riau. J. Online 
Mahasiswa Fakultas Perikanan dan IImu Kelautan Universitas Riau, 1 (1):1-15.

Behrenfeld, M.J. \& Boss, E.S. 2014. Resurrecting the ecological underpinnings of ocean plankton blooms. Ann Rev Mar Sci. 6:167194

Case, M., Leca, E.E., Leitao, S.N., Sant'Anna, E.E., Schwamborn, R., \& de Moraes, A.T., 2008. Plankton community as an indicator of water quality in tropical shrimp culture ponds. Mar. Poll. Bull. 56:1343-1352.

Ghinaglia, L. T., Herrera-Silveira, J. A., \& Francisco, A. C., 2004. Structural variations of phytoplankton in the coastal seas of Yucatan, Mexico. Hydrobiologia, 519(1-3): 85-102. doi: 10.1023/b:hydr.000 0026487.78497.b6

Hutabarat, S. \& Evans, S.M., 1986. Kunci Identifikasi Zooplankton Daerah Tropik. UI Press. Jakarta.

Kumar, V., Roy S., Meena, D.K., \& Sarkar, U.K., 2016. Application of probiotics in shrimp aquaculture: importance, mechanisms of action, and methods of administration. Rev Fish Sci Aquac. 24:342-368

Landa, M., Blain, S., Christaki, U., Monchy, S. \& Obernosterer, I., 2016. Shifts in bacterial community composition associated with increased carbon cycling in a mosaic of phytoplankton blooms. Isme J. 10:39-50

Liao, S.A., Li, Q., Wang, A.L., Xian, J.A., Chen, X.D., Gou, N.N., Zhang, S.P., Wang, L., \& XU, X.R., 2012. Effect of nitrite on immunity of the white shrimp Litopenaeus vannamei at low temperature and low salinity. Ecotoxicology. 21:1603-1608

Logue, J.B., Stedmon, C.A., Kellerman, A.M., Nielsen, N.J., Andersson, A.F., Laudon, H., Lindstrom, E.S., \& Kritzberg, E.S., 2016. Experimental insights into the importance of aquatic bacterial community composition to the degradation of dissolved organic matter. Isme J. 10:533545

Madinawati. 2010. Kelimpahan dan Keanekaragaman Plankton di Perairan Laguna Desa Tolongano Kecamatan Banawa Selatan. Media Litbang Sulteng, 3(2):119-123.

Marsambuana, P.A. 2008. Hubungan Keragaman Fitoplankton dengan Kualitas Air di Pulau Bauluang, Kabupaten Takalar, Sulawesi Selatan.
Balai Riset Perikanan Budidaya Air Payau, Maros. J. Biodiv., 9(3):22-217.

Meirinawati, H., \& Muchtar, M. 2017. Fluktuasi Nitrat, Fosfat dan Silikat di Perairan Pulau Bintan. J. Segara, 13(3):141-148

Nontji. 2006. Tiada Kehidupan di Bumi Tanpa Keberadaan Plankton. Lembaga Ilmu Pengetahuan Indonesia. Jakarta.

Odum, E.P. 1998. Dasar-dasar Ekologi (Fundamentals of Ecology). Diterjemahkan oleh Tj. Samingan. Gajah Mada University Press, Yogyakarta

Praseno, D.P \& Sugestiningsih.2000. Retaid di Perairan Indonesia.P3O-LIPI.

Putri, C.R., Djunaedi, A. \& Subagyo, S., 2019. Ekologi Fitoplankton: Ditinjau dari Aspek Komposisi, Kelimpahan, Distribusi, Struktur Komunitas dan Indeks Saprobitas Di Perairan Morosari, Demak. J. Mar. Res., 8(2):197-203.

Romimohtarto, K. \& Juwana, S. 2001. Biologi Laut. Ilmu Pengetahuan tentang biota laut. Penerbit Djambatan, Jakarta, 540.

Sihombing, R.F., Aryawati, R. \& Hartoni. 2013. Kandungan Klorofil-a Fitoplankton di Sekitar Perairan Desa Sungsang Kabupaten Banyuasin Provinsi Sumatera Selatan. J. Maspari, 5(1):34-39.

Yamaji, I. 1996. Illustrations of the marine plankton of Japan.4th Printing, Hoikushu Publ. Co., Osaka.

Yang, W., Zhu, J., Zheng, C., Lukwambe, B., Nicholaus, R., LU, K., \& Zheng, Z., 2019., Succession of phytoplankton community during intensive shrimp (Litopenaeus vannamei) cultivation and its effects on cultivation systems. Aquaculture, (in press) doi: 10.1016/j.aquaculture.2019.73 4733

Ye, Y., Chen, B., Zhou, Q., Wang, Y., Chen, Y., \& Lin, M., 2019. Phytoplankton community structure during monsoon transition period in the Lembeh Strait of North Sulawesi, Indonesia. Journal of King Saud University Science (In Press) doi: 10.1016/ j.jksus.2019.10.013

Youyin, Y., Kaibiao, C., Qianqian, Z., Peng, X., Yunlong, H., \& Mao, L. 2018. Impacts of thermaldischarge on phytoplankton in Daya Bay. J. Coast. Res., 83:135-147 doi: 10.2112/SI83-022.1. 